\title{
PEMBERIAN TERAPI MUROTAL QUR'AN TERHADAP NYERI SAAT PERAWATAN LUKA POST OP LAPAROTOMI DI RUANG KUTILANG RS.Dr.H.ABDUL MOELOEK PROVINSI LAMPUNG
}

\author{
Marliyana \\ Akademi keperawatan Baitul Hikmah Bandar Lampung \\ Email : marliyana.nafa@yahoo.com
}

\begin{abstract}
ABSTRAK
Nyeri adalah sensori subjektif dan emosional yang tidak menyenangkan yang didapat terkait dengan kerusakan jaringan aktual maupun potensial, atau menggambarkan kondisi terjadinya kerusakan. Pasien yang mengalami nyeri, perlu dilakukan tindakan untuk mengurangi nyeri salah satunya adalah terapi murotal Qur'an. Berdasarkan data dari RS.Hi.Abdul Moeloek pada bulan Desember 2016 sampai dengan Mei 2017 menunjukkan bahwa terdapat 250 pasien atau 24,6\% yang memerlukan tindakan bedah laparotomi dari 1013 pasien yang memerlukan tindakan bedah lainnya. Tujuan penelitian ini adalah untuk mengetahui pengaruh pemberian terapi murotal Qur'an terhadap penurunan skala nyeri saat perawatan luka di ruang kutilang RS. Dr.Hi.Abdul Moeloek Provinsi Lampung. Jenis penelitian ini adalah kuantitatif dengan desain quasi eksperimen menggunakan rancangan one group pretest post test design. Penelitian ini dilaksanakan pada bulan Juni sampai Agustus 2017. Subyek dalam penelitian ini adalah 30 orang pasien post laparotomi di ruang kutilang RS Dr.Hi.Abdoel Moeloek. Uji hipotesis dengan uji paired sample t-test. Hasil analisa univariat diperoleh bahwa sebelum pemberian tindakan terapi murotal Qur'an rata-rata skala nyeri yaitu 9,25 dan setelah pemberian tindakan terapi murotal Qur'an terjadi penurunan skala nyeri menjadi 0.68 Hasil analisis bivariat diketahui ada pengaruh pemberian terapi murotal Qur'an terhadap skala nyeri pasien post op laparatomi saat dilakukan perawatan luka di ruang kutilang RS Dr.Hi.Abdoel Moeloek tahun 2017 (pvalue $=0,000$ ). Bagi perawat diharapkan dapat memberikan terapi Murotal Qur'an sebagai alternatif dalam pemberian terapi non farmakologis.

Kata Kunci :Nyeri, Murotal Qur'an, Post Op Laparotomi
\end{abstract}

\begin{abstract}
Pain is a subjektive and emotionally unpleasant sensation that is acquired related to actual or potential tissue damage, or describes the condition of the occurrence of damage. Patients who experience pain, they need to take action to reduce pain one of them is murotal Qur'an therapy. Based on data from RS.Hi.Abdul Moeloek in January to may 2017, that showed there are 250 patients or 24,6\% who need other surgical procedures. The purpose of this study was to determine the effect that we give murotal qur'an therapy on reducing pain scale when wound care in the kutilang RS.Dr.Hi.Abdul Moelok Lampung Province. The type of this research is quantitative with a quasi-experimental design using the design of one group pre test and post test design. This research was conducted in june to august 2017. The subject in this study were 30 patients post laparotomy in kutilang RS.Dr.Hi.Abdul Moeloek Lampung Province. Hypothesis testing by paired sample t-test. Univariate analysis result obtained that before giving murotal qur'an therapy the average pain scale was 9,25 and after giving the murotal qur'an therapy on pain scale of post op laparotomy during wound care in the kutilang RS.Dr.Hi.Abdul Moeloek Lampung Province 2017 (p-value=0,000). For further research especially for nurse it is suggested to use murotal Qur'an, murotal Qur'an theraphy as an alternative in providing non-pharmacological therapy.
\end{abstract}

Keywords: Pain, Murotal Qur'an, Post Laparotomy $O p$ 


\section{PENDAHULUAN}

Perkembangan globalisasi dan perubahan gaya hidup manusia berdampak terhadap perubahan pola penyakit. Beberapa tahun terakhir masyarakat Indonesia mengalami perkembangan dan peningkatan angka kesakitan dan kematian. Untuk mengatasi berbagai macam keluhan penyakit, mulai dari tindakan yang paling ringan yaitu secara konservatif atau non bedah sampai tindakan yang paling berat yaitu operatif atau tindakan bedah (Potter dan Perry, 2006).

Tindakan pembedahan bertujuan untuk mencegah kecacatan dan komplikasi, dimana tindakan ini menjadi terapi pilihan pada berbagai kondisi yang sulit dan tidak mungkin disembuhkan melalui obat-obatan sederhana. Pasien yang mendapatkan tindakan pembedahan semakin banyak. Hal ini dibuktikan dengan tindakan operasi dibeberapa rumah sakit dari tahun ke tahun yang cenderung semakin meningkat (Potter dan Perry, 2006).

Data WHO menunjukkan bahwa selama lebih dari satu abad, perawatan bedah telah menjadi komponen penting dari perawatan kesehatan. Di perkirakan setiap tahun ada 230 juta tindakan bedah dilakukan di seluruh (Hasri, 2012). Pembedahan merupakan tindakan pengobatan invasif yang dilakukan oleh tim medis untuk mengatasi masalah medis dengan membuka atau menampilkan bagian tubuh yang akan ditangani melalui sayatan dan akhirnya ditutup dengan penjahitan luka (Susetyowati,dkk, 2010).

Klasifikasikan tindakan pembedahan menjadi dua, yaitu bedah mayor dan minor. Salah satu tindakan bedah mayor adalah laparotomi (Potter dan Perry, 2006). Laparotomi merupakan salah satu prosedur pembedahan mayor dengan cara melakukan penyayatan pada dinding abdomen untuk mendapatkan organ dalam abdomen yang mengalami masalah , misalnya kanker, perdarahan, obstruksi, dan perforasi (Sjamsuhidayat ,et al, 2010 ).

Laparotomi merupakan salah satu tindakan bedah abdomen yang beresiko 4,46 kali terjadinya komplikasi infeksi pasca operasi dibanding tindakan bedah lainnya ( Haryanti, et al, 2013). Menurut Data Tabulasi Nasional Departemen Kesehatan Republik Indonesia tahun 2009, menjabarkan bahwa tindakan bedah menempati urutan ke-11 dari 50 pola penyakit di Indonesia dengan presentase $12,8 \%$ dan diperkirakan $32 \%$ diantaranya merupakan tindakan bedah laparotomi. Data dari Rumah Sakit Dr.Cipto Mangunkusumo Jakarta bulan juli- desember 2004 menyebutkan adanya operasi laparotomi emergensi terhadap 83 orang penderita dengan mortality rate mencapai 9 orang atau 
$10,84 \%$ dan yang mengalami komplikasi infeksi sebanyak 19 orang ( $44,19 \%)$ (Yuwono, 2013).

Menurut Kristiantari (2009) masalah keperawatan yang terjadi pada pasien post laparotomi meliputi pelemahan (memburuknya keadaan), keterbatasan fungsi tubuh yang cacat. Pelemahan meliputi nyeri akut pada bagian lokasi operasi, takut dan keterbatasan LGS (Lingkup Gerak Sendi). Keterbatasan fungsi tubuh meliputi ketidakmampuan berdiri, berjalan, serta ambulasi dan cacat meliputi aktivitas yang terganggu karena keterbatasan gerak akibat nyeri dan prosedur medis.

Nyeri yang hebat merupakan gejala sisa yang diakibatkan oleh operasi pada regio intraabdomen, sekitar $60 \%$ pasien menderita nyeri yang hebat, $25 \%$ nyeri sedang dan $15 \%$ nyeri ringan. (Nugroho,2010). Dalam periode pasca perioperatif, proses keperawatan diarahkan pada menstabilkan kembali equilibrium fisiologi pasien, menghilangkan rasa nyeri dan pencegahan komplikasi (Purwanto,2008).

Metode penatalaksanaan nyeri mencakup pendekatan farmakologis dan non farmakologis. Salah satu pendekatan nonfarmakologis adalah distraksi. Distraksi mengalihkan perhatian pasien ke hal yang lain dan dengan demikian menurunkan kewaspadaan terhadap nyeri bahkan meningkatkan toleransi terhadap (Purwanto,2008). Salah satu tekhnik distraksi untuk pereda nyeri adalah terapi murotal Qur'an. Murrotal Qur'an adalah terapi bacaan Al Qur'an yang merupakan terapi religi dimana seseorang dibacakan ayat-ayat AlQur'an (Hadi,dkk, 2013).

Berdasarkan data dari RS.Hi.Abdul Moeloek pada bulan Januari sampai dengan Mei 2017 menunjukkan bahwa terdapat 250 pasien atau $24,6 \%$ yang memerlukan tindakan bedah laparotomi dari 1013 pasien yang memerlukan tindakan bedah.

Berdasarkan fenomena diatas penulis tertarik untuk membuat studi kasus tentang penerapan terapi murotal untuk menurunkan nyeri pada saat perawatan luka post op laparotomi. Di Ruang Kutilang RSUD.Hi. Abdul Moelok Provinsi lampung.

\section{METODOLOGI}

Jenis penelitian ini adalah kuantitatif dengan desain quasi eksperimen menggunakan rancangan one group pretest post test design. Penelitian ini dilaksanakan pada bulan Juni sampai Agustus 2017. subyek penelitian ini adalah seluruh pasien post operasi laparatomi yang di rawat diruang kutilang RS Dr.Hi.Abdoel Moeloek pada bulan Juni 
sampai dengan Agustus 2017 dengan jumlah 30 orang, kriteria pasien tidak memiliki gangguan pendengaran, pasien dengan kesadaran composmentis. pasien yang sedang menjalani perawatan luka, pasien mengalami nyeri perawatan luka dengan rentang nyeri ringan sampai sedang (4-6). Uji hipotesis dengan uji paired sample t-test.

\section{HASIL}

\section{A. ANALISA UNIVARIAT}

Tabel 1. Nyeri sebelum dilakukan terapi

Murotal Qur'an pada saat perawatan pasien post operasi laparatomi

\begin{tabular}{lllll}
\hline Variabel & Mean & SD & T & p-value \\
\hline Nyeri & 9,25 & 0,65 & 19,37 & 0,00 \\
pasien & & & & \\
Sebelum & & & & \\
intervensi & & & & \\
\hline
\end{tabular}

Berdasarkan tabel 1 diatas, distribusi frekwensi nyeri pasien sebelum dilakukan perawatan luka sebelum diberikan terapi murotal Qur'an di ruang kutilang RS Rs.Dr.Hi.Abdul Moeloek Provinsi Lampung rata - rata nyeri yaitu 9,25

\section{ANALISA BIVARIAT}

Tabel 2. Nyeri Pasien saat dilakukan perawatan luka setelah dilakukan tindakan terapi murotal Qur'an

\begin{tabular}{lcccc}
\hline Variabel & Mean SD & T & $\begin{array}{c}p \\
\text { value }\end{array}$ \\
\hline $\begin{array}{l}\text { Nyeri pasien } \\
\text { Setelah }\end{array}$ & 0,68 & 0,65 & 19,37 & 0,00 \\
intervensi & & & & \\
\hline
\end{tabular}

Berdasarkan tabel 2 diatas, distribusi frekwensi nyeri pasien saat dilakukan perawatan luka di ruang kutilang RS

.Dr.Hi.Abdul Moeloek Provinsi Lampung memiliki rata-rata nyeri 0,68 .

\section{B. ANALISA BIVARIAT}

Tabel 3. Pengaruh pemberian terapi murotal Qur'an terhadap nyeri pada saat di Lakukan perawatan luka post op

Laparatomi

\begin{tabular}{lccccc}
\hline Variabel & Mean & & SD & T & $\begin{array}{c}p- \\
\text { value }\end{array}$ \\
\hline $\begin{array}{l}\text { Nyeri } \\
\text { Pretest }\end{array}$ & 9,25 & 0,65 & 19,37 & 0,00 \\
\hline $\begin{array}{l}\text { Nyeri } \\
\text { Posttest }\end{array}$ & 0,68 & 0,65 & 19,37 & 0,00 \\
\hline
\end{tabular}

Berdasarkan tabel 3 diatas dapat diketahui bahwa uji t-(paired sample t-test) terhadap rata-rata nyeri sebelum dan sesudah diberikan tindakan yaitu terapi murotal Qur'an diperoleh nilai signifikasi $p$-value $=0,000(p$ value 0,05), maka dapat disimpulkan bahwa ada pengaruh pemberian terapi murotal Qur'an terhadap penurunan nyeri pada saat dilakukan perawatan luka pasien post op laparatomi di ruang kutilang RS.Dr.Hi.Abdul Moeloek Provinsi Lampung tahun 2017.

\section{PEMBAHASAN}

A. ANALISA UNIVARIAT

1. Nyeri pada saat perawatan luka pasien post operatif sebelum diberikan terapi murotal Qur'an

Berdasarkan hasil penelitian diperoleh disribusi frekwensi nyeri pada saat setelah dilakukan terapi murotal Qur'an di ruang 
kutilang RS.Dr.Hi.Abdul Moeloek

Provinsi Lampung memiliki rata 9,25 dengan skala nyeri sedang.

Menurut Menurut International Association For Study Of Pain (IASP) nyeri adalah sensori subjektif dan emosional yang tidak menyenangkan yang didapat terkait dengan kerusakan jaringan actual maupun potensial, atau menggambarkan kondisi terjadinya kerusakan (Lyndon, 2013).

Pengalaman nyeri seseorang dipengaruhi oleh beberapa faktor, yaitu 1) Arti atau Makna Nyeri Nyeri bersifat sangat subjektif sehingga memiliki arti atau makna yang berbeda setiap orang. Arti nyeri dipengaruhi oleh usia, jenis kelamin, lingkungan, latar belakang social budaya, serta pengalaman nyeri sekarang dan masa lalu, 2) Persepsi Nyeri Persepsi nyeri merupakan penilaian yang sangat subjektif yang berpusat di area korteks,3) Toleransi Terhadap Nyeri Toleransi terhadap nyeri berhubungan erat dengan intensitas nyeri yang membuat seseorang sanggup menahan nyeri sebelum meminta bantuan dari orang lain, 4) Reaksi terhadap Nyeri Reaksi seseorang pada saat mengalami nyeri berbeda-beda (Lyndon, 2013)

2. Nyeri pada saat dilakukan perawatan luka setelah diberikan terapi murotal Qur'an
Berdasarkan hasil penelitian diperoleh bahwa nyeri pasien saat dilakukan perawatan luka setelah dilakukan terapi murotal Qur'an pada pasien post op laparotomi di ruang kutilang RS.Dr.Hi.Abdul Moeloek Provinsi Lampung memiliki rata-rata 0,68 , dan berada pada rentan nyeri ringan.

Menurut Hadi,dkk (2013) salah satu metode mengurangi nyeri adalah dengan distraksi/mengalihkan perhatian pasien ke hal yang lain dan dengan demikian menurunkan kewaspadaan terhadap nyeri bahkan meningkatkan toleransi terhadap nyeri. Salah satu tekhnik distraksi untuk pereda nyeri adalah terapi murotal Qur'an. Murrotal Qur'an adalah terapi bacaan $\mathrm{Al}$ Qur'an yang merupakan terapi religi dimana seseorang dibacakan ayat-ayat AlQur'an.

Menurut Utami, Rahma \& safitri (2016) tujuan terapi murotal Qur'an yaitu : menurukan hormon-hormon stress, mengaktifkan hormon edorfin alami, meningkatkan perasaan rileks, mengalihkan perhatian dari rasa takut, cemas, dan rasa sakit.

Efek murotal Qur'an secara fisiologis dapat bertindak melalui stimulasi efektor reseptor mekanisme. Murotal Qur'an 
dengan keteraturan irama, tempo lambat, lembut penuh penghayatan dan bacaan yang benar mampu mendatangkan ketenangan, meminimalkan kecemasan, dan dapat menimbulkan suatu respon relaksasi.

Pada penelitian ini nyeri pasien saat dilakukan perawatan luka setelah diberikan terapi murtal Qur'an mengalami penurunan dibandingkan sebelum diberikan tindakan. Hal ini dapat disebabkan karena terapi murotal Qur'an memberikan efek terhadap nyeri pada pasien yang sedang dilakukan perawatan luka. Analisa lebih lanjut akan dibahas pada pada analisa bivariat.

\section{B. ANALISA BIVARIAT}

\section{Pengaruh Pemberian terapi Murotal Qur'an terhadap penurunan nyeri pasien post op laparatomi saat perawatan luka}

Bedasarkan hasil penelitian diperoleh bahwa ada pengaruh pemberianterapi murotal Qur'an terhadap penurunan skala nyeri pada pasien post op laparatomi yang sedang dilakukan perawatan luka di ruang kutilang RS.Dr.Hi.Abdul Moeloek Provinsi Lampung tahun 2017 ( $p$-value $=0,000)$.

Hasil penelitian menunjukkan adanya penurunan skala nyeri pada pasien post op laparatomi setelah 5 hari berturut -turut diberikan terapi murotal Qur'an, dengan nilai rata-rata 0,68 skala nyeri ringan sampai tidak nyeri. Hasil penelitian Aldriyanto, (2012) meneliti tentang terapi murotal Qur'an pada pasien post section caesarea dan berhasil menurunkan nyeri 12 dari 13 respondennya, sedangkan 1 orang responden mengalami nyeri tetap.

Sejalan dengan penelitian aldriyanto hasil penelitian Harsiwi, T (2014) tentang terapi murotal Qur'an pada siswi yang mengalami nyeri desminorea primer. Sebanyak 15 responden, 12 responden mengalami nyeri intensitas sedang dan 3 responden merasakan nyeri intensitas berat. Setelah pemberian terapi murotal Qur'an terjadi penurunan intensitas nyeri desminorea yang dirasakan oleh seluruh respondennya. Dari 15 responden penelitian, 11 responden merasakan nyeri dengan intensitas ringan dan 4 responden lainnya merasakan nyeri dengan intensitas sedang.

Hal ini sesuai dengan teori yang diungkapkan oleh Alexander (2007) dalam Saputra, 2017 bahwa terapi Murotal dapat menurunkan nyeri, karena memiliki efek distraksi dalam inhibisi persepsi nyeri. Murotal juga dipercaya meningkatkan pengeluaran hormone endorphin yang memiliki efek rileks dan ketenangan yang timbul, midbrain mengeluarkan Gama Amino Butyric Acid (GABA) yang berfungsi menghambat 
hantaran impuls listrik dari satu neuron ke neuron lainnya oleh neurotransmitter di dalam sinaps. Selain itu, midbrain juga mengeluarkan enkepalin dan beta endorphin. Zat tersebut dapat menimbulkan efek analgesia yang akhirnya mengeliminasi neurotransmitter di dalam sinaps. Selain itu, midbrain juga mengeluarkan enkepalin dan beta endorphin. Zat tersebut dapat menimbulkan efek analgesia yang akhirnya mengeliminasi neurotransmitter rasa nyeri pada pusat persepsi dan interpretasi sensorik somatic di otak. Sehingga efek yang bisa muncul adalah nyeri berkurang.

Saat seseorang mendengarkan musik atau murotal Qur'an, gelombangnya ditransmisikan melalui assicles di telinga tengah dan melalui cairan cochlear berjalan menuju telinga dalam. Membran basilaris cochlea merupakan area resonansi dan berespon terhadap frekuensi getaran yang bervariasi. Rambut silia sebagai sensori reseptor yang mengubah frekuensi getaran menjadi getaran elektrik dan langsung terhubung dengan ujung nervus pendengaran. Nervus auditori menghantarkan sinyal ini ke korteks euditori di lobus temporal. Korteks auditori primer menerima input dan mempersepsikan pitch dan melodi yang rumit, dan dipengaruhi oleh pengalaman seseorang. Korteks auditori sekunder lebih lanjut memproses interpretasi musik sebagai gabungan harmoni, melodi, dan rhytm

(Wilgram, 2007) Mekanisme murotal dalam memberikan efek penurunan nyeri telah dijelaskan dalam teori Gate Control, dimana kesan yang muncul bahwa transmisi dari hal yang berpotensi sebagai impuls nyeri bisa dimodulasikan oleh "cellular gating mechanium" ditemukan di spinal cord. Gate Control Theory menyatakan bahwa sinyal nyeri yang ditransmisikan dari bagian yang mengalami cedera melalui reseptor-reseptor nervus di spinal, lalu sinaps-sinaps menyampaikan informasi ke otak (Bally, dkk, 2008).

Hal ini juga diperkuat dengan pendapat Macgregor dalam Faradisi (2012), bahwa Saat gerbang tertutup, sinyal nyeri akan dicegah mencapai otak. Namun saat gerbang membuka, impuls-impuls tersebut akan mampu mencapai otak dan menginformasikan pesan sebagai nyeri. Saat impuls sensori lain yang dikirim (murrotal Qur'an) bersamaan dengan berjalannya impuls nyeri, maka impuls-impuls ini akan berkompetisi untuk mencapai otak. Pada keadaan gerbang baik terbuka maupun tertutup, musik dipercaya dapat mengurangi persepsi nyeri pasien.

\section{KESIMPULAN}

Berdasarkan hasil analisa data dan pembahasan dapat disimpulkan bahwa : distribusi frekwensi nyeri sebelum dilakukan 
tindakan terapi Murotal Qur'an pada pasien post op laparatomi di ruang Kutilang RS.Dr.Hi.Abdul Moeloek Provinsi Lampung dengan rata-rata nyeri 9,25 berada pada nyeri sedang, distribusi frekwensi nyeri setelah diberikan tindakan terapi murotal Qur'an di pada pasien post op laparatomi di ruang Kutilang RS.Dr.Hi.Abdul Moeloek Provinsi Lampung memiliki rata-rata nyeri 0.68 dengan nyeri ringan, ada pengaruh pemberian tindakan terapi murotal Qur'an terhadap penurunan instensitas nyeri di ruang Kutilang RS.Dr.Hi.Abdul Moeloek Provinsi Lampung tahun 2017 ( $p$ value $=0,000)$.

\section{SARAN}

Perawat diharapkan dapat memberikan terapi Murotal Qur'an sebagai alternatif dalam pemberian terapi non farmaklologis. Dan hasil penelitian dapat digunakan sebagai dasar penelitian selanjutnya tentang terapi spiritual lain misalnya dengan zikir dalam menangani pasien yang mengalami nyeri.

\section{KEPUSTAKAAN}

Aldriyanto. (2012) Pengaruh Terapi Audio Murottal Ar-Rahman Terhadap Intensitas Nyeri Pada Pasien Post Operasi SectioCaesaria, PSIK STIKES “Aisyiyah Yogyakarta.

Saputra. (2017). Pengaruh pemberian murottal

Al - Qur'an dan musik klasik terhadap tekanan darah pada pasien pra operasi, Skripsi, UIN Alauddin Makassar

Bedah Unhas. (2013). Tinjauan Umum Laparotomi. $\quad$ http://erepo.unud.ac.id. Dilihat 07 Mei 2017.
Faradis, Firman. (2012). Efektivitas Terapi Murotal dan Terapi Musik Klasik terhadap Penurunan Tingkat Kecemasan Pasien Pra Operasi di Pekalongan. Jurnal Ilmiah Kesehatan. Vol V No. 2 September 2012

Hadi, dkk. 2013. Obati Dirimu Dengan AlQur'an, Tangerang: Iniperbesa.

Handayani,R, (2014). Pengaruh Terapi Murotal Qur'an, http://download.Portalgaruda.org/articl e.php?article $=297669 \& \mathrm{val}=6633 \&$ title =PENGARUH\%20TERAPI\%20MUR OTT, Dilihat 04 April 2017.

Harsiwi, Tria. (2014). Pengaruh Alunan Murotal Terhadap Intensitas Nyeri Dismenorea Primer Pada Siswi Madrasah Mu'alimaat Muhammadiyah Yogyakarta. Dilihat 02 Mei 2017.

Haryanti, dkk. (2013). Tinjauan Umum Laparotomi. http://erepo.unud.ac.id/10004/3/7743c d8b82943e7cf29b8ddb84390ec8.pdfdi lihat. 4 Mei 2017.

Hasri. (2012). BAB I $p d f$. http://thesis.umy.ac.id. Dilihat 02 Mei 2017.

Potter\&Perry, (2006), Buku Ajar Fundamental Keperawatan, Jakarta:EGC.

Purwanto, Budhi, (2012), Herbal dan Keperawatan Komplementer, Nuha Medika: Yogyakarta.

Purwanto, E, Sumarni, DW, Sutono, (2008). Efek musik terhadap perubahan intensitas nyeri pada pasien post operasi di ruang bedah cendana 2 RSUP dr Sarjito Yogjakarta, JIK, Vol.03/No.02/Mei/2008 
Lyndon, 2013, Pengantar Kebutuhan Dasar Manusia, Tangerang: Binarupa Aksara.

Kristiantari, 2009, Hubungan antara karakteristik demografi dengan pengetahuan mobilisasi dini pada pasien post operasi laparatomi di RS PKU Muhammadiyah Bantul, Thesis UMY

Nugroho,W, 2008, Keperawatan gerontik dan geriatrik, edisi 3,Jakarta, EGC

Sjamsuhidayat. 2010. Tinjauan Umum Laparotomi.

http://erepo.unud.ac.id/10004/3/7743c d8b82943e7cf29b8ddb84390ec8.pdfdi lihat. 4 Mei 2017.

Utami,S, Rahma \& Safitri, 2015, Efektifitas murotal Qur'an terhadap intensitas nyeri persalinan kala I, JOM Vol 2 No.2,

Wilgram, A.,L, 2007, The effect of vibroacoustic therapy on clinical therapy and non-clinical population. St, Georges Hospital Mdical School London University.

Yuwono. 2013. BAB I $p d f$. http://thesis.umy.ac.id. Dilihat $02 \mathrm{Mei}$ 2017. 